\title{
THE MAIN CHANGES OF STUDENTS' VOLUNTEER ACTIVITIES IN A RUSSIAN LARGE REGION (SVERDLOVSK REGION)
}

\author{
Pevnaya Maria1, Telepaeva Daria ${ }^{2 \star}$ \\ 1Dr., Ural Federal University, RUSSIA, usovet info@mail.ru \\ ${ }^{2}$ Mrs., Ural Federal University, RUSSIA, daria.telepaeva@gmail.com \\ ${ }^{*}$ Corresponding Author
}

\begin{abstract}
This article analyzes the survey's results of University students in the Sverdlovsk region. It compares the data of the sixth (2012) and seventh (2016) stages of sociological monitoring. Volunteering in this study is explored as part of the civic engagement of Ural youth. The poll was conducted by questioning students from 14 universities of Sverdlovsk region ( $\mathrm{N}=1802$; type of sample is random-stratified). The sample included $34 \%$ men and $66 \%$ women. The sample included students who receive education on humanitarian $(40 \%)$, socioeconomic $(26 \%)$, science $(11 \%)$, and technical $(28 \%)$ specialty.

In the questionnaires of 2012 and 2016, respondents were asked: "Did you take part in volunteer activities in the last year?" It has allowed to distinguish among the students of 4 groups: students without experience in volunteer activities; students who accidentally took part in volunteer projects 1-2 times; the students working as volunteers from time to time (4-5 times in year); students who worked as volunteer constantly (1-2 times per month).

The respondents' answers help to assess the regularity of students' volunteer activities from different areas of training. Monitoring data allowed to fix the increase in the share of regular working volunteers students humanitarians (29\% in 2012 against 35\% in 2016) and reduction among them those 1 or 2 times participated in volunteer projects. These changes are evaluated as positive as global experience shows that for a variety of professional specialties social sector, volunteering plays an important role in the professionalization of young specialists. Technology of "learning by action" is implemented in Russian universities recently. This is a very important issue, because such changes characterize the tendency of cooperation between higher educational institutions, organizations of the social sphere and non-profit organizations.
\end{abstract}

Significantly increased the number of those who have never been involved in volunteer projects among students of science and engineering (10\% and $6 \%$ respectively). In our opinion, such changes have a direct relationship with the transformation of the educational and upbringing activities in Russian universities. The main way of higher education's development focuses primarily on the scientific development and international cooperation of universities. This trend may indicate a consequence of underestimating the educational and training functions of the University's environment.

To evaluate the motives and incentives of students' volunteer activity in the questionnaire were asked: "Under what conditions would you agree to become a volunteer?" Respondents could choose no more than 
three of the nine alternatives.

The monitoring results have allowed to record changes in the motivation of students receiving education in different areas of training.

The comparison of survey data of 2012 and 2016 years demonstrated a reduction in the number of students in humanitarian, socio-economic and natural science specialties, which under no circumstances will deal with volunteering in the future. For 4 years not only the number of engineering students (one in five) who are not interested in volunteering has changed,

Communications volunteer activities with educational activities would motivate more humanities students and techies.

We recorded an increased importance of career motivation for volunteering among all students of the Middle Ural, with $7 \%$ in 2012 to $19 \%$ in 2016. Alternative to "If I helped it make a successful career" was important to $23 \%$ of engineering students $(2012-10 \%)$, increased by $10 \%$ the number of students among the humanities (2012 - 7\%, $2016-17 \%)$. The relationship of volunteering with career development seems to be less important for students receiving education in natural science: in 2012 it was $9 \%$, and in $2016-12 \%$.

External incentives - "good organization of volunteer activities and special education" - are the least important motives for technical specialties and students of natural-science direction.

Keywords: Volunteering, student volunteering, young people, civic engagement, sociological monitoring.

\section{INTRODUCTION}

Civic engagement of youth is one of the most important theme for the sociological research today. Youth as a social group is characterized by social, cultural, personal features. Skills, knowledge, abilities, skills and actions are distinctive in the youth as compared other age groups. Social capital of student's youth has a cumulative effect. Russian national policy is addressed to university students. The future of any country, its economic and demographic development depends on the young generation. Moreover, the students are the actors of civil society development.

By the end of the twentieth century, Russian youth has become an active and powerful social actor. Youth civic engagement in the socially approved sense can occur if they begin to feel like a full member of society, to feel that someone can really help, for something to influence. (Omelchenko, 2005, p. 74). In Russia, as in other developed countries, students of universities become the most active people in the public sphere.

University communities aim to have a positive impact for all involved: the city public and economy benefit through increased student engagement; the higher education institutions benefit through enhanced collaborative working and enhanced recognition of the collective role of higher education within the city economy and community; and students benefit from a step change in collaboration and engagement. (Clayton, Longhurst, Willmore, Bigg, Brooks, DareEdwards, Darwen, di Corpo, Gough, Heywood, Hills, Howells, Hyland, Idle, Khan, Miller, Owen, Sharratt, Talbot, Tierney, Tweddell, and Walsh, 2016, p.114). One of the most popular types of youth civic engagement is a volunteering. This activity is actively supported by the state authority of Russia in the last 10 years.

High level of volunteerism among students across the sampled universities in Australia, Canada, New Zealand, the U.K., and the USA (Cnaan, Smith, Holmes, Haski-Leventhal, Handy, Brudney, 2010, p. 6581). There is a large number of student volunteers in Russian universities. It's positive for educational institutions and governments that seek to encourage volunteerism by students and young people (HaskiLeventhal, Meijs, Hustinx, 2009, p. 139-158).

In 2014, Russia has created a national Association of volunteer centers as a consequence of the volunteer program "Sochi 2014". The Association comprises 55 profile centers "Sochi 2014" from 30 regions of Russia. All centers operate in universities. More than 100 educational institutions are included in the national volunteer movement (Pervushina, 2014, p. 112-116). The recruitment and training of students and volunteers is conducted in universities professionally.

Russia actively undergoes the reform of higher education, changing the content of the training and its' organization in accordance with the Bologna Agreement. In Russian universities, the technology of learning through volunteering is at the beginning, as a modern practice-oriented approach to learning, rapidly developing in many universities around the world (Falko, Konovalova, 2012, p. 73-79). Thus, the reform 
processes lead to the fact that profile of volunteering in Russian students is changing.

Thus, the purpose of the article is to analyze the features of student volunteering in one of the largest Russian regions receiving higher education in different areas of training.

\section{STUDENT VOLUNTEERING RESEARCH AND SOME THEORETICAL IDEAS}

Today accumulated comparative study of youth volunteering (Hustinx, Handy, Cnaan, Brudney, Pessi, Yamauchi, 2010, p. 349-382.) is illustrated mainly by conducting research in individual countries (Simha, Topuzova, Albert, 2011, p. 107-126).

Sociologists study student participation in public and political life of a whole country or of regions. Some scientific papers are devoted to the problems of young volunteers in some non-profit organizations and the organization of student volunteering in universities. In Russia volunteering is evaluated for the last 20 years. Sociologists study volunteering of different age groups and regions. Lately, they examine the role of volunteering in University training and education, its relationship to professional training of students.

The particular interest of researchers is aimed at problems of young people, their personal and professional development. Voluntary work as a dimension for the development of character, personal development and a venue for developing people's skills (which universities and employers often seek in their processes of recruitment) (Gray, 2010, p. 95-109).

For understanding the nature of volunteer activities an important characteristic is its regularity. The amount of time that a person spends on volunteering, according to the researchers, is associated with the perceived motivations and benefits of student volunteering (Cnaan, Smith, Holmes, Haski-Leventhal, Handy, Brudney, 2010, p. 67).

Thus, the institutional environment (infrastructure, changing of training) in universities can affect the change of the student volunteer movement. Gradual incorporation into volunteering of those students who intend to work in the social sphere is significant. In this context, our research questions are: a profile of education does the degree of involvement of students in volunteering and the regularity of their activities? As submitted by volunteering in the life plans of young people? How does motivation for volunteering among students of different profiles training?

\section{DATA AND METHOD}

This article analyzes the survey's results of University students in the Sverdlovsk region. It compares the data of the sixth (2012) and seventh (2016) stages of sociological monitoring. Volunteering in this study is explored as one of the types of civic activism in Ural youth. The poll was conducted by questioning students from 14 universities of Sverdlovsk region ( $\mathrm{N}=1802$; type of sample is random-stratified). The sample included $34 \%$ boys and $66 \%$ girls. The sample included students who receive education on humanitarian $(40 \%)$, socio-economic $(26 \%)$, science $(11 \%)$, technical $(28 \%)$ areas.

Method of data processing is a correlation analysis. It is the method of processing statistical data involved examining the correlations between variables. The correlation coefficients are compared between one pair or multiple pairs of signs to establish between statistical relationships.

The research methodology allowed us to assess the regularity of volunteer activity of students of different areas of training. In the questionnaires of 2012 and 2016, respondents were asked: "Did you take part in volunteer activities in the last year?" It has allowed distinguishing among the students of 4 groups: students without experience in volunteer activities; students who accidentally took part in volunteer projects 1-2 times; the students working as volunteers from time to time (3-6 times every year); students who worked as volunteer constantly ( 7 times and more every year). The amount of time spent by students on volunteer projects, in our view, reflects their involvement in the environment (daily practice), activity, community.

An important indicator of the inclusion of volunteering in student life plans is their desire to participate in volunteer projects in the future. Respondents were asked the dichotomic question: "Do you plan to continue volunteering activity?"

According to the analysis, respondents were allocated a group of students (86\%) for which the volunteer activity was included in their life plans. In the study we evaluated their motives and incentives. To evaluate the motives and incentives of students' volunteer activity in the questionnaire, the following questions were asked: "Under what conditions would you agree to become a volunteer?" Respondents could choose no more than three of the eight alternatives. In the questionnaire the Respondent could choose alternatives, which were further combined into larger groups: altruistic motives, selfish motives and external incentives. The Group of altruistic motives included the following alternatives: "If I knew that my help is 
needed by some specific people", "Opportunity to improve life in the house, the street, the area". The Group of selfish motives included the following answers: "If it helped me make a successful career", "If it would help me in studies", "If I have new friends". The group of motives, external environment, we have identified the following alternatives: "If someone organized everything and invited me to take part", "If I knew that it would be interesting and fun organized", "If I taught this".

\section{THE RESULTS}

An important aspect of the study of student volunteering' dynamics was evident in the analysis of the Ural students' involvement of different training areas in volunteer activities. The data presented in Tab. 1.

Table 1- The participation of students of different training areas in volunteer activities (\% of respondents in groups)

\begin{tabular}{|c|c|c|c|c|c|c|c|c|}
\hline \multirow{3}{*}{$\begin{array}{l}\text { Alternative of answers } \\
\text { The year of survey }\end{array}$} & \multicolumn{8}{|c|}{ Areas of training } \\
\hline & \multicolumn{2}{|c|}{ Humanitarian } & \multicolumn{2}{|c|}{$\begin{array}{l}\text { Social and } \\
\text { economic }\end{array}$} & \multicolumn{2}{|c|}{ Natural-scientific } & \multicolumn{2}{|c|}{ Technical } \\
\hline & 2012 & 2016 & 2012 & 2016 & 2012 & 2016 & 2012 & 2016 \\
\hline $\begin{array}{l}\text { Yes, I constantly work } \\
\text { as the volunteer }\end{array}$ & 7 & 6 & 7 & 3 & 8 & 7 & 6 & 2 \\
\hline $\begin{array}{l}\text { Yes, from time to time } \\
\text { I participate in } \\
\text { volunteer projects }\end{array}$ & $\underline{22}$ & $\underline{29}$ & 22 & 24 & 24 & 22 & 14 & 18 \\
\hline $\begin{array}{c}\text { Yes I did by accident } 1 \\
\text { time }\end{array}$ & $\underline{28}$ & $\underline{20}$ & 27 & 28 & $\underline{30}$ & $\underline{23}$ & $\underline{26}$ & $\underline{21}$ \\
\hline No, never had & 43 & 45 & 44 & 45 & $\underline{38}$ & $\underline{48}$ & $\underline{53}$ & $\underline{59}$ \\
\hline TOTAL: & 100 & 100 & 100 & 100 & 100 & 100 & 100 & 100 \\
\hline
\end{tabular}

The survey data show a growth by $10 \%$ of the number of students of natural-scientific profile and by $6 \%$ in the number of engineering students who have no experience in volunteer activities. The number of students which incidentally participated in volunteer projects among is natural-scientific students on $7 \%$ has decreased. In 2012, 1-2 times took part in volunteer projects of $30 \%$ students of this profile, in $2016-23 \%$. The reduction of "accidental volunteers" is located among students-technicians. In 2012 1-2 times each fourth student of this group (26\%) was engaged, in 2016 such experience had only everyone the fifth (21 $\%)$. We witnessed a reduction of the number of regularly employed young volunteers among groups of students socio-economic and technical profiles. In each group their fraction has decreased for $4 \%$. By results of questioning the assessment is given to plans of students in relation to volunteer activities.

Table 2- Students of different training areas, planning to continue volunteering in the future (\% of respondents in groups)

\begin{tabular}{|c|c|c|c|c|c|}
\hline \multirow{2}{*}{$\begin{array}{c}\text { The year } \\
\text { of survey }\end{array}$} & \multicolumn{5}{|c|}{ Areas of training } \\
\cline { 2 - 6 } & Humanitarian & Social and economic & Natural-scientific & Technical & TOTAL: \\
\hline 2012 & 82 & 81 & 87 & 78 & 82 \\
\hline 2016 & 85 & 87 & 92 & 79 & 86 \\
\hline
\end{tabular}

Table 2 shows that overall the number of students planning to volunteer in the future increased by $4 \%$. In 2012 these students was $82 \%$, in $2016-86 \%$. In 4 years increased by $6 \%$ the number of students who receive education on the socio-economic profile, whose volunteer activities are included in the life plans. On $5 \%$ the fraction of such students has increased in group of naturally scientific profile (in $2012-87 \%, 2016-$ $92 \%)$. 
IJASOS- International E-Journal of Advances in Social Sciences, Vol. III, Issue 7, April 2017

Table 3- The motives and incentives of students-volunteers of different training areas

(\% of respondents in groups)

\begin{tabular}{|c|c|c|c|c|c|c|c|c|}
\hline \multirow{2}{*}{$\begin{array}{c}\text { The motives and } \\
\text { incentives }\end{array}$} & \multicolumn{9}{|c|}{ Areas of training } \\
\cline { 2 - 10 } & \multicolumn{2}{|c|}{ Humanitarian } & \multicolumn{2}{c|}{$\begin{array}{c}\text { Social and } \\
\text { economic }\end{array}$} & \multicolumn{2}{c|}{ Natural-scientific } & \multicolumn{2}{c|}{ Technical } \\
\hline The year of survey & 2012 & 2016 & 2012 & 2016 & 2012 & 2016 & 2012 & 2016 \\
\hline Altruistic motives & $\underline{\mathbf{3 8}}$ & $\underline{\mathbf{2 8}}$ & $\underline{\mathbf{3 8}}$ & $\underline{\mathbf{2 9}}$ & 33 & 31 & 35 & 25 \\
\hline Selfish motives & 35 & 57 & 37 & 41 & 40 & 38 & 39 & 49 \\
\hline External incentives & 27 & 15 & 25 & 30 & 28 & 31 & 26 & 26 \\
\hline $\begin{array}{c}\text { The average number } \\
\text { of chosen } \\
\begin{array}{c}\text { alternatives in the } \\
\text { group }\end{array}\end{array}$ & 1,3 & 1,8 & 1,2 & 1,8 & 1,5 & 1,8 & 1,2 & 1,6 \\
\hline
\end{tabular}

For 4 years the number of students of humanists and technicians has decreased for $10 \%$, the number of students economists has decreased for $9 \%$, for whom it is important altruistic basis of their volunteer activities. For $22 \%$ (from $35 \%$ in 2012 to $57 \%$ in 2016) has increased the number of students in humanitarian specialties, on $10 \%$ became more students-technicians (from $39 \%$ in 2012 to $49 \%$ in 2016), which chose the selfish motives of participation in volunteering. External incentives - organization of volunteer projects, training activities - became less important for humanists, the number of students who chose the alternatives in this group among them decreased on $8 \%$.

\section{CONCLUSIONS AND DISCUSSION}

Monitoring data allowed us to fix the increase in the share of regular working volunteers humanitarian students (29\% in 2012 against $35 \%$ in 2016) and a reduction among them those who participated in volunteer projects only 1 or 2 times. These changes are evaluated as positive as global experience shows that for a variety of professional specialties such as social workers and psychologists, volunteering play an important role in the professionalization of young specialists. In Russia it is widespread to apply the technology of "learning by action". This is a very important change, because such changes characterize the tendency of cooperation between higher educational institutions, organizations of the social sphere and organizations in non-profit sector on a sectoral basis.

Significantly we witnessed a decrease of the number of those who have never been involved in volunteer projects among students of science and engineering (10\% and $6 \%$ respectively). In our opinion, such changes have a direct relationship with the transformation of the educational and upbringing activities in Russian universities. The main direction of higher education's development mainly focuses on scientific development and international cooperation of universities. This trend may indicate a latent nature of underestimating the educational function of the University environment.

The comparison of survey data of 2012 and 2016 years demonstrated a reduction in the number of students in humanitarian, socio-economic and natural science specialties, which under no circumstances will deal with volunteering in the future. For 4 years the number of engineering students (one in five), who are not interested in volunteer activities has changed. A comparison of the data leads to the conclusion that the potential of volunteer participation among all students is not yet exploited, especially among natural-scientific and economic areas of training.

Volunteer activity of students largely depends on the areas of training. The results can be tracked for 4 years to further research this phenomenon.

The reduction of altruistic motives is observed in all groups of students. The growth in the trend of selfish motives reduction of altruistic motives is disturbing for understanding the volunteering students who, in accordance with their specialization, should work in the social sphere. Probably the revealed variations are connected with an individualization, pragmatization and rationalization of volunteering. According to $P$. Dekker and L. Halman, individualization might be the most important valuable change currently affecting volunteers and what they do (Dekker, Halman, 2003, p. 227-248). Maybe the growth of selfish motivation in students is associated with problems in the labor market, which shortly there will be students of universities. Researchers note that in the countries with lower rates of inflation and unemployment the number of volunteers is higher (Hackl, Halla, Pruckner, 2012, p. 465-495). For humanists conditions of the organization of volunteer activity and training become ever less meaningful. Probably, it is connected with their variation 
training and gradual inclusion of volunteer activity in their professional training.

\section{ACKNOWLEDGMENTS}

The research is supported by the Russian Foundation for Humanities (Project № 16-03-00016).

\section{REFERENCE LIST}

Clayton, W., Longhurst, J., Willmore, C., Bigg, M., Brooks, I., DareEdwards, E., Darwen, J., di Corpo, R., Gough, G., Heywood, G., Hills, S., Howells, L.-K., Hyland, F., Idle, J., Khan, H., Miller, K., Owen, D., Sharratt, J., Talbot, H., Tierney, A., Tweddell, H. and Walsh, A. (2016). The Bristol Method: Green Capital Student Capital. The power of student sustainability engagement. Documentation. Retrieve from http://eprints.uwe.ac.uk/28828

Cnaan, R. A., Smith, K. A., Holmes, K., Haski-Leventhal, D., Handy, F., Brudney, J. L. (2010). Motivations and Benefits of Student Volunteering: Comparing Regular, Occasional, and NonVolunteers in Five Countries. Canadian Journal of Nonprofit and Social Economy Research, 1 (1). Retrieve from http://repository.upenn.edu/spp_papers/153

Dekker, P., Halman, L. (2003). The Values of Volunteering: Cross-Cultural Perspectives. British Journal of Social Work. 6 (30).

Falko, L. Y., Konovalova, N. A. (2012). The modernization of the educational process based on the model of practice-based education. University management: practice and analysis. 4 (3).

Gray, B. (2010). The Rise of Voluntary Work in Higher Education and Corporate Social Responsibility in Business: Perspectives of Students and Graduate Employees. Journal of Academic Ethics. 8 (3). Retrieve from http://link.springer.com/article/10.1007\%2Fs10805-010-9105-0

Hackl, F., Halla, M., Pruckner, G. (2012). Volunteering and the State. Public Choice. 151 (3).

Haski-Leventhal, D., Meijs, L., Hustinx, L. (2009). The third party model: Enhancing volunteering through governments, corporations and educational institutes. Journal of Social Policy. 39 (1).

Hustinx, L., Handy, F., Cnaan, R., Brudney, J., Pessi, A., Yamauchi, N. (2010). Social and cultural origins of motivations to volunteer: A comparison of university students in six countries. International Sociology. 25 (3).

Omelchenko, E. L. (2005). Youth activism in Russia in context of global transformations. The journal of social policy studies. 3 (1).

Pervushina, E. A. (2014). Development of volunteer activities at higher education institution. The higher education in Russia. 11 (3).

Simha, A., Topuzova, L., Albert, J. (2011). V for Volunteer(ing). The Journeys of Undergraduate Volunteers. Journal of Academic Ethics. 9 (2). 